\title{
SEGITIGA KEMISKINAN-PERTUMBUHAN-KETIMPANGAN (PGI TRIANGLE): PEMBANGUNAN KEUANGAN, PEMBANGUNAN MANUSIA, DAN KETIMPANGAN PENDAPATAN DI ASIA
}

\author{
POVERTY-GROWTH-INEQUALITY TRIANGLE (PGI TRIANGLE): \\ FINANCIAL DEVELOPMENT, HUMAN DEVELOPMENT, \\ AND INEQUALITY IN ASIA
}

\author{
Rivanda Fadhila Indra Putra ${ }^{1}$, Vera Lisna ${ }^{2}$ \\ ${ }^{1}$ Badan Pusat Statistik Kabupaten Tojo Una-Una, rivanda@bps.go.id \\ ${ }^{2}$ Pusat Pendidikan dan Pelatihan BPS RI, veralisna@bps.go.id
}

\begin{abstract}
Abstrak
Salah satu isu yang dihadapi oleh negara-negara di Asia adalah ketimpangan pendapatan. Solusi untuk ketimpangan adalah melalui pembangunan ekonomi, termasuk di dalamnya pembangunan keuangan (financial development). Sektor finansial berperan penting dalam perekonomian suatu negara, perkembangan sektor finansial secara tidak langsung akan meningkatkan output dari sektor sektor lain sehingga mengikatkan nilai Produk Domestik Bruto (PDB) atau dapat dikatakan terjadi pertumbuhan ekonomi. Selain pemerataan pendapatan dan pertumbuhan ekonomi, dalam pembangunan ekonomi juga perlu dilihat kaitan keduanya dengan pembangunan manusia sebagaimana dikatakan dalam segitiga kemiskinan-pertumbuhan ekonomi-ketimpangan (poverty-growthinequality triangle/PGI Triangle). Tujuan dari penelitian ini adalah untuk melihat gambaran dari ketimpangan distribusi pendapatan, pembangunan keuangan, dan pembangunan manusia di enam negara Asia. Analisis yang digunakan adalah statistik deskriptif dan regresi data panel khususnya fixed effect model (FEM) dan random effect model (REM). Hasil penelitian menunjukkan bahwa terdapat pengaruh signifikan antara pembangunan keuangan dan pembangunan manusia terhadap ketimpangan pendapatan. Semakin tinggi pembangunan keuangan akan mengurangi tingkat ketimpangan dari suatu negara, sedangkan nilai pembangunan manusia yang tinggi justru meningkatkan ketimpangan.
\end{abstract}

Kata kunci: pembangunan keuangan, ketimpangan, pembangunan manusia, regresi panel

Klasifikasi JEL: C33; E44; G21; O16

\begin{abstract}
One of the issues faced by countries in Asia is income inequality. Economic development is expected to improve people's living standards to minimize the gap between low-income and high-income populations. One of economic development is through financial development. The financial sector plays an important role in the economy of a country, the development of the financial sector will indirectly increase the output of other sectors so as to tie the value of the Gross Domestic Product (GDP). In addition to equality and economic growth, economic development also needs to see whether the two are related to human development as described in the poverty-growth-inequality triangle (PGI Triangle). The purpose of this study is to see a picture of the inequality of income distribution, financial development and human development in six Asian countries. The analysis used descriptive statistics and panel data regression, specifically fixed effect model (FEM) and the random effect model (REM). The result showed that there is a significant influence between financial development and human development on income inequality, the higher the financial development will reduce the level of inequality of a country. Meanwhile, the high value of human development actually increases inequality.
\end{abstract}

Keywords: financial development, income inequality, human development, panel regression

JEL Classification: C33; E44; G21; O16 


\section{PENDAHULUAN}

Dalam proses pembangunan ekonomi suatu negara, terdapat dua pendekatan dalam rangka pengentasan kemiskinan, yaitu harus memprioritaskan pertumbuhan ekonomi, atau penyetaraan distribusi pendapatan (penghapusan ketimpangan). Pertumbuhan ekonomi dapat menyebabkan peningkatan dan juga penurunan ketimpangan sehingga terjadi keterkaitan kompleks antara kemiskinan, pertumbuhan ekonomi, dan ketimpangan pendapatan. Hal ini yang kemudian melatarbelakangi munculnya model Poverty-Growth-Inequality (PGI) Triangle. Contoh dari penerapan PGI Triangle adalah Tiongkok pasca reformasi, pertumbuhan ekonomi di Tiongkok telah membantu mengangkat 270 juta orang miskin di perdesaan keluar dari kemiskinan selama tahun 1980-2000. Kebijakan ini memang efisien, tetapi tidak mempertimbangkan distribusi pendapatan yang memungkinkan adanya kemiskinan lain di masa depan (Wan, 2008). Distribusi pendapatan akan menggambarkan rata atau timpangnya pembagian hasil dari pembangunan suatu negara di kalangan penduduknya. Distribusi pendapatan yang tidak merata akan menyebabkan ketimpangan pendapatan yang berdampak pada penurunan tingkat kesejahteraan penduduk. Distribusi pendapatan yang tidak merata secara teori dapat diminimalisir melalui pembangunan ekonomi. Pembangunan ekonomi diharapkan bisa meningkatkan standar hidup masyarakat, terutama yang berpendapatan rendah sehingga dapat meminimalisir gap antara penduduk berpendapatan rendah dan berpendapatan tinggi.

Tujuan dari pembangunan ekonomi adalah peningkatan ketersediaan serta pemerataan distribusi berbagai barang kebutuhan pokok, peningkatan standar hidup untuk memperbaiki kesejahteraan materiil dan nilai-nilai moral (Todaro, 2006). Dalam membangun perekonomian suatu negara, peran sektor finansial atau sektor keuangan tidak dapat diabaikan. Meskipun pengaruh langsung sektor finansial terhadap PDB lebih kecil daripada sektor riil, peran dari sektor finansial ini secara tidak langsung dapat meningkatkan akumulasi modal yang dapat meningkatkan output dari sektor riil itu sendiri, yang akan berdampak pada kenaikan PDB atau pertumbuhan ekonomi (Shaw \& McKinnon, 1973). Pembangunan keuangan (financial development) ini sendiri akan mengarah kepada pembangunan ekonomi yang akan mempersempit jurang ketimpangan antara penduduk berpendapatan rendah dengan penduduk berpendapatan tinggi.

Menurut beberapa ahli ekonomi, pembangunan keuangan seharusnya dapat mengurangi ketimpangan pendapatan melalui beberapa cara. Menurut Galor \& Zeira (1993), dengan adanya pembangunan keuangan penduduk dengan pendapatan rendah lebih mudah mendapatkan kredit. Kredit tersebut akan digunakan sebagai modal untuk memulai suatu usaha atau dapat juga meningkatkan kualitas hidup mereka seperti pendidikan dan kesehatan. Perluasan kredit swasta dapat menstimulasi pertumbuhan pendapatan penduduk dengan pendapatan rendah dan mengurangi ketimpangan pendapatan (Rajan \& Zingales, 2003).

Menurut laporan United Nations Development Programme (UNDP, 2013) dalam Human Development Report 2013, kawasan Asia Pasifik mengalami peningkatan koefisien gini sebesar 13 persen. Laporan tersebut juga menyebutkan bahwa ketimpangan distribusi pendapatan di negara berpendapatan tinggi (high income countries) lebih kecil yakni sebesar 9 persen dibanding negara yang berpendapatan rendah (low/middle income countries) sebesar 11 persen. Negaranegara Asia menurut klasifikasi World Bank masih memiliki tingkat ketimpangan sedang, dibuktikan dengan rata-rata nilai rasio gini yang di atas batas wajar yaitu 0,40 (Bock, 2014). Dalam mengurangi ketimpangan diperlukan adanya pembangunan ekonomi, salah satunya adalah perkembangan dari sektor finansial. Sektor finansial yang tidak berkembang dengan baik akan memperparah ketimpangan antara penduduk berpendapatan tinggi dengan penduduk berpendapatan rendah/ miskin. Selain dari pembangunan ekonomi, juga perlu dilihat kaitannya dengan pengentasan kemiskinan suatu negara. Menurut Sen (1976), kemiskinan suatu negara tidak dapat digambarkan hanya dengan pendekatan moneter, namun juga harus ditinjau dari aspek yang lebih luas seperti pembangunan manusia. 


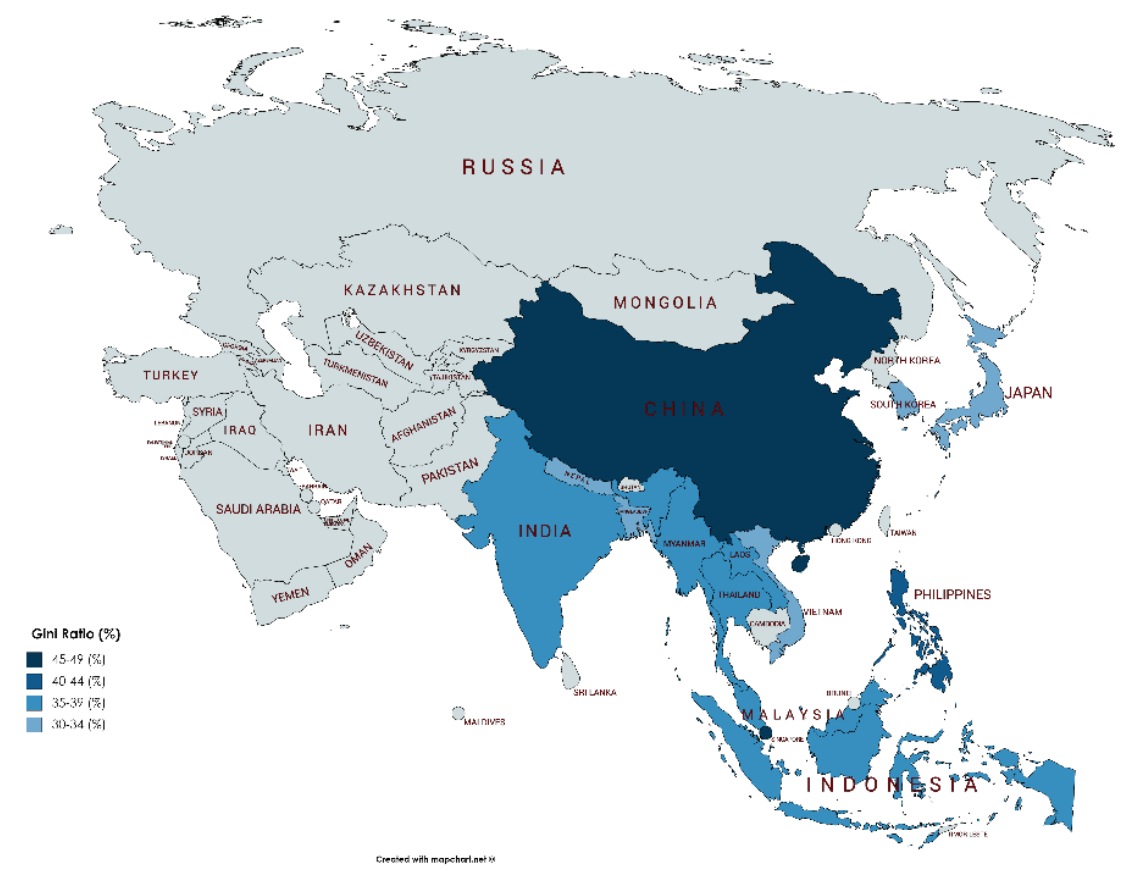

Gambar 1. Rasio gini Asia tahun 2016

Sumber: World Bank (2018)

Buhaerah (2017) dalam penelitiannya yang mengukur pengaruh proses finansialisasi dalam perekonomian terhadap distribusi pendapatan di ASEAN-5 menggunakan variabel kapitalisasi pasar, Return on Asset (RoA), dan utang swasta domestik. Dengan menggunakan model data panel dinamis Arellano-Bond, dihasilkan bahwa kapitalisasi pasar dan $R o A$ berkorelasi positif dengan distribusi pendapatan. Sementara, penelitian Astuti (2013) yang menggunakan Private Credit to GDP sebagai proksi pembangunan keuangan, menghasilkan bahwa pembangunan keuangan berpengaruh signfikan negatif terhadap ketimpangan pendapatan di negara maju.

Keenam negara Asia menurut klasifikasi World Bank masih memiliki tingkat ketimpangan yang sedang, yaitu di atas 0,35 dan di bawah 0,5. Selain itu, menurut Bock (2014) di atas batas wajar dibuktikan dengan rata-rata nilai rasio gini yang di atas 0,40 . Ketimpangan tersebut menimbulkan kemakmuran untuk sebagian kelompok tetapi juga menimbulkan kemiskinan untuk sebagian kelompok lainnya. Ini berarti bahwa pendapatan riil dari yang kaya tumbuh jauh lebih cepat daripada yang miskin, yang pada akhirnya akan merembet ke masalah kesejaheraan lain (Kindleberger, 1988).

Dalam mengurangi ketimpangan, diperlukan adanya pembangunan ekonomi, salah satunya adalah pembangunan dari sektor finansial. Sektor finansial yang tidak berkembang dengan baik akan memperparah ketimpangan antara penduduk berpendapatan tinggi dengan penduduk berpendapatan rendah/miskin. Selain itu, perkembangan dari sektor finansial dapat mempengaruhi alokasi modal, yang tidak hanya berefek pada pertumbuhan ekonomi secara umum, tapi juga pada permintaan kerja sehingga akan mempengaruhi tingkat pendapatan masyarakat.

Sayangnya, pertumbuhan ekonomi yang cepat belum tentu berdampak positif terhadap pembangunan. Justru pertumbuhan ekonomi yang cepat akan memperparah ketimpangan, karena pertumbuhan ekonomi sejatinya tidak selalu diikuti dengan pemerataan. Ada trade off antara pertumbuhan ekonomi yang tinggi dengan pemerataan pembangunan dalam suatu pembangunan (Kuncoro, 2006). Hal yang sama juga dipaparkan oleh Kuznets (1955) dengan hipotesis "U-terbalik" yang mengatakan 
bahwa ketimpangan akan meningkat seiring dengan pertumbuhan ekonomi. Hubungan antara pertumbuhan ekonomi dan ketimpangan pendapatan yang baik pada akhirnya akan berujung pada pengentasan kemiskinan.

Berdasarkan pemaparan di atas, peneliti ingin mengetahui apakah terdapat keterkaitan antara pembangunan keuangan (financial development), ketimpangan distribusi pendapatan, dan kemiskinan. Serta bagaimana ketiganya mempengaruhi satu sama lain? Apakah benar dengan adanya pembangunan keuangan akan menurunkan tingkat ketimpangan, atau justru akan meningkatkan tingkat ketimpangan yang akhirnya akan memperparah kemiskinan sebagaimana disebutkan dalam kurva Kuznets?

\section{TINJAUAN LITERATUR}

Masalah yang sering timbul adalah apa fokus utama dari pengentasan kemiskinan. memprioritaskan pertumbuhan ekonomi, atau penyetaraan distribusi pendapatan (penghapusan ketimpangan). Perubahan kemiskinan di suatu negara sangat dipengaruhi oleh perubahan pertumbuhan dan ketimpangan pendapatan (Bourguignon, 2004). Hubungan antara ketiganya dianggap sebuah tantangan nyata untuk membangun strategi pembangunan, disebut juga sebagai PGI Triangle. Model ini berbeda dengan model-model kemiskinan lainnya karena model ini melihat interaksi antara pertumbuhan ekonomi dan ketidaksetaraan/ketimpangan, daripada mempertimbangkan keduanya secara terpisah. Model ini mengisyaratkan bahwa pengentasan kemiskinan memerlukan kombinasi kebijakan

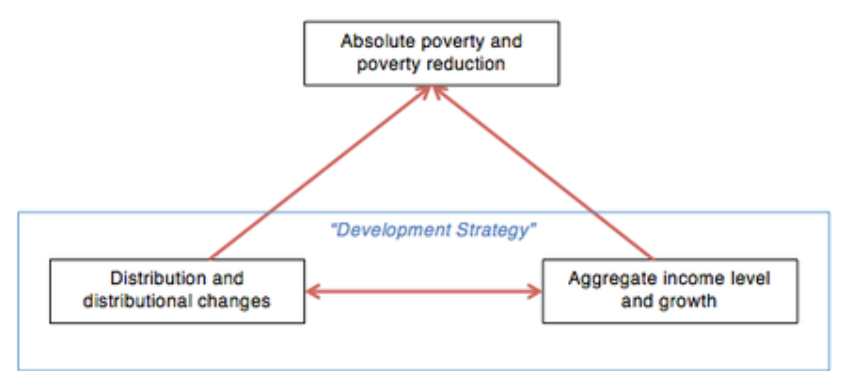

\section{PGI Triangle}

Gambar 2. Konsep PGI Triangle

Sumber: The Poverty-Growth-Inequality Triangle (Bourguignon, 2004) yang berfokus pada pertumbuhan ekonomi dan juga pengurangan ketimpangan, bukan hanya fokus kepada salah satu kebijakan.

\section{Pengaruh Pembangunan Keuangan terhadap Ketimpangan Pendapatan}

Pembangunan keuangan (financial development) dapat dianggap sebagai bentuk dari pertumbuhan ekonomi. Kuznets (1955) mengatakan bahwa hubungan antara pertumbuhan ekonomi dan ketimpangan berbentuk kurva U terbalik, dengan sumbu $\mathrm{X}$ adalah pertumbuhan ekonomi dan Y ketimpangan pendapatan. Pada masa awal pembangunan, pertumbuhan ekonomi akan meningkatkan ketimpangan pendapatan, dapat dilihat dengan kurva slope positif, akan tetapi setelah pertumbuhan terus berjalan dalam jangka panjang, pertumbuhan ekonomi akan menurunkan ketimpangan pendapatan (kurva dengan slope negatif). Dalam penelitian Persson \& Tabellini (1991), disimpulkan bahwa terdapat pengaruh negatif yang signifikan antara pertumbuhan ekonomi dan ketimpangan pendapatan di negara yang demokratis. Galor \& Zeira (1993) dalam penelitiannya mengatakan bahwa dengan adanya pembangunan keuangan membuat kredit lebih mudah diakses oleh penduduk yang berpendapatan rendah. Kredit nantinya akan digunakan untuk modal usaha ataupun meningkatkan usaha mereka. Selain itu, kredit juga dapat digunakan untuk meningkatkan kualitas hidup, seperti kesehatan dan pendidikan.

Sementara, Jallian \& Kirkpatrick (2005) mengatakan bahwa terdapat hubungan yang cukup kompleks antara pembangunan keuangan terhadap ketimpangan pendapatan, karena hubungan bisa terjadi secara langsung maupun tidak langsung. Pada awalnya pembangunan keuangan akan meningkatkan akumulasi kapital di sektor-sektor produksi barang dan jasa. Modal yang meningkat akan disertai dengan peningkatan output sehingga terjadi pertumbuhan ekonomi. Pertumbuhan ekonomi secara tidak langsung akan memicu peningkatan aspek-aspek ekonomi yang lain, seperti peningkatan permintaan akan tenaga kerja, peningkatan infrastruktur dan naiknya tingkat upah. Harapannya, hal tersebut dapat dimanfaatkan oleh penduduk berpenghasilan rendah untuk meningkatkan kualitas hidup mereka. 


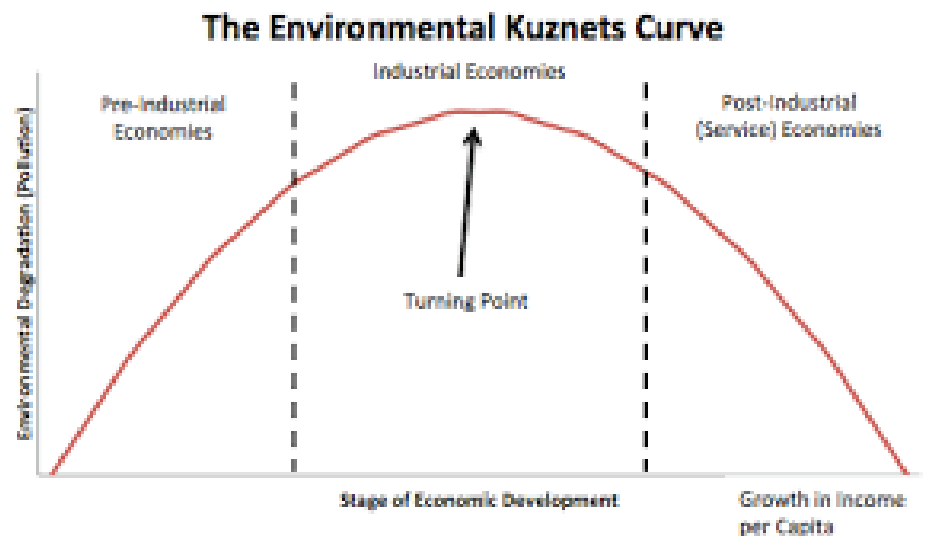

Gambar 3. Kurva U-Inverted Kuznets

Sumber: Kuznets's Inverted U-Curve Hypothesis: The Rise, Demise, and Continued Relevance of a Socioeconomic Law (2005)

\section{Pembangunan Keuangan}

Menurut Levine (2005), pembangunan keuangan mencakup perbaikan, pemutakhiran fungsifungsi yang disediakan oleh sistem finansial seperti penyatuan tabungan, pengalokasian modal untuk investasi produktif, pemantauan investasi, dan pertukaran barang dan jasa. Dengan meningkatnya peran dari sektor finansial, diharapkan dapat meningkatkan akumulasi modal sehingga tercipta pertumbuhan ekonomi (Shaw \& McKinnon, 1973). Tidak ada definisi khusus yang menjelaskan pembangunan keuangan, sehingga dapat ditarik kesimpulan bahwa tidak ada ukuran mutlak untuk mengukur besarnya pembangunan keuangan suatu negara. Namun, working paper International Monetary Fund (IMF) pada tahun 2016 dengan judul Introducing a New Broad-based Index of Financial Development membagi ukuran pembangunan keuangan ke dalam empat dimensi, yaitu kedalaman (depth), akses (access), efisiensi (efficiency) dan stabilitas (stability) untuk melakukan proksi. Masingmasing dimensi memiliki beberapa indikator, diantaranya disebutkan dalam Tabel 1.

Tabel 1. Indikator untuk mengukur pembangunan keuangan

\begin{tabular}{ll}
\hline Kategori & Indikator \\
\hline \multicolumn{1}{c}{ Lembaga Keuangan } \\
\hline Kedalaman (depth) & $\begin{array}{l}\text { Private-sector credit to } \\
\text { GDP }\end{array}$ \\
\hline Efisiensi (efficiency) & Return on Equity \\
\hline Stabilitas (stability) & Bank Z-Score \\
\hline
\end{tabular}

Sumber: IMF (2016)

\section{Rasio Kredit Swasta dengan GDP}

Rasio kredit swasta terhadap PDB menggambarkan kedalaman finansial (financial depth). Rasio kredit swasta terhadap PDB mencakup semua kredit yang dikeluarkan untuk sektor swasta oleh lembaga finansial dibagi dengan PDB. PDB mewakili pendapatan suatu negara. Semakin tinggi rasio kredit swasta terhadap PDB di suatu negara, semakin tinggi pengembangan lembaga keuangan di negara tersebut.

\section{Return on Equity (ROE)}

ROE merupakan pengembalian atas ekuitas saham biasa yang digunakan untuk mengukur tingkat laba yang dihasilkan dari investasi pemegang saham.

\section{Bank Z-Score}

Z-Score adalah ukuran stabilitas suatu perusahaan, dalam hal ini Bank Z-Score berarti stabilitas suatu bank atau sistem keuangan suatu negara. Dalam Peraturan Bank Indonesia Nomor 16/11/ PBI/2014 tentang Pengaturan dan Pengawasan Makroprudensial, stabilitas sistem keuangan merupakan suatu kondisi di mana sistem keuangan nasional berfungsi dengan efektif dan efisien serta mampu bertahan dari kerentanan internal maupun eksternal. Hal ini menyebabkan pendanaan ataupun pembiayaan dapat berkontribusi terhadap pertumbuhan serta stabilitas ekonomi nasional.

\section{Ketimpangan Pendapatan}

Ketimpangan pendapatan secara singkat dapat dikatakan sebagai perbedaan kesejahteraan antar golongan pendapatan penduduk. World Bank (2009), menyebut ketimpangan pendapatan sebagai konsep yang lebih luas daripada kemiskinan, ketimpangan didefinisikan atas seluruh populasi, tidak hanya penduduk yang berada di bawah garis kemiskinan. Ketimpangan pendapatan terjadi ketika pendapatan yang dihasilkan masyarakat dari golongan yang berbeda memiliki perbedaan yang sangat mencolok (Todaro, 1994). Ketimpangan pendapatan yang bernilai tinggi mengindikasikan tidak meratanya distribusi pendapatan atau dapat diartikan pendapatan golongan kaya tumbuh jauh lebih cepat dibandingkan golongan miskin (Kindleberger, 1988). Ketimpangan pendapatan 
umumnya diukur oleh sebuah koefisien atau indeks yang disebut dengan rasio gini.

\section{Rasio gini}

Besarnya ketimpangan pendapatan umumnya diukur oleh sebuah indeks atau koefisien yang sering disebut rasio gini. Rasio gini merupakan ukuran numerik agregat ketimpangan pendapatan mulai dari 0 hingga 1 . Distribusi pendapatan dikatakan merata jika angka rasio gini kecil atau mendekati nol, sedangkan semakin besar nilai rasio gini atau mendekati angka 1 , semakin tidak merata distribusi pendapatan (Todaro, 1994)

\section{Kemiskinan}

Berdasar pada konsep World Bank (2015), seseorang akan dianggap miskin jika memiliki penghasilan kurang dari suatu standar pendapatan. Sama halnya dengan BPS yang mengukur kemiskinan melalui garis kemiskinan. Tetapi kemiskinan tidak hanya dimaknai sebagai ketidakmampuan dari sisi ekonomi saja, tetapi harus ditinjau dari aspek yang lebih luas. Hal ini dibahas oleh Sen (1976) yang mengatakan bahwa kemiskinan merupakan suatu kondisi dimana masyarakat tidak mampu untuk memenuhi kebutuhan primer, tidak memiliki pendapatan, kondisi kesehatan yang buruk, kurangnya akses pendidikan yang memadai, tidak merasa aman, tidak percaya diri atau merasa tidak berdaya ataupun tidak memiliki hak kebebasan berbicara. Pendekatan moneter tidak dapat mengantisipasi keadaan dimana seseorang yang telah dianggap mampu berdasar penghitungan moneter atau garis kemiskinan, namun masih menghadapi berbagai persoalan, seperti fasilitas kesehatan dan pendidikan layak. Berdasarkan konsep yang dicanangkan oleh Sen tersebut, dapat disimpulkan kemiskinan merupakan persoalan multidimensi yang memerlukan pendekatan nonmoneter, tidak cukup hanya diukur dengan menggunakan pendekatan moneter (Bappenas, 2006).

\section{Human Development Index (HDI)}

HDI diciptakan untuk menekankan bahwa kemampuan manusia harus diperhitungkan dalam penilaian perkembangan suatu negara, bukan hanya pertumbuhan ekonomi semata. HDI merupakan indeks komposit yang dihitung sebagai rata-rata geometrik dari 3 indeks yang menggambarkan kemampuan dasar manusia dalam memperluas pilihan, mencakup dimensi pendidikan, kesehatan, dan pengeluaran (daya beli). Indeks pembangunan manusia suatu negara menunjukkan kualitas sumber daya manusia yang nantinya akan membangun negara tersebut. Jika kualitas sumber daya manusia meningkat, maka akan mendorong produktivitas kinerja. Yang pada akhirnya akan menghasilkan output yang tinggi pula, sehingga akan mendorong kesejahteraan orang tersebut ke arah yang lebih baik dan dapat keluar dari kemiskinan.

\section{Indeks Pembangunan Manusia (IPM) dan Ketimpangan Pendapatan}

Jika suatu daerah memiliki nilai IPM yang baik, maka dapat dianggap bahwa daerah tersebut memiliki Sumber Daya Manusia yang mumpuni dan akan mempunyai peluang untuk sejahtera. Peningkatan IPM pada suatu daerah yang tidak diiringi dengan peningkatan IPM di daerah lainnya akan memicu terjadinya ketimpangan distribusi pendapatan (Brata, 2002).

\section{METODE PENELITIAN}

\section{Pengumpulan Data}

Data yang digunakan adalah rasio gini sebagai pendekatan dari Ketimpangan Distribusi Pendapatan, dengan nilai berkisar antara $0 \sim 1$. Jika 0 berarti tidak terdapat ketimpangan, sedangkan 1 berarti ketimpangan mutlak. Pendekatan Pembangunan Keuangan diperoleh dari tiga variabel yaitu Private Credit to GDP, Return on Equity, dan Bank Z Score. Ketiga variabel ini masing masing menjelaskan tingkat pembangunan keuangan dari suatu negara sebagaimana disebutkan dalam Tabel 1. Sementara, untuk pembangunan manusia menggunakan variabel HDI yang merupakan indeks komposit yang dihitung sebagai rata-rata geometrik dari 3 indeks yang menggambarkan kemampuan dasar manusia dalam memperluas pilihan, mencakup dimensi pendidikan, kesehatan, dan pengeluaran (daya beli).

Data yang digunakan dalam penelitian ini adalah data sekunder dari tahun 2004 hingga tahun 2016 (update terbaru dari dataset Global Financial Development Database (GFDD) Oktober 2019, 
World Income Inequality Database (WIID) Mei 2020, dan UNDP 2019 dari enam negara di Asia yaitu Indonesia, Malaysia, Singapura, Thailand, Filipina, dan Tiongkok.

Untuk data rasio gini diperoleh dari WIID, proksi dari Pembangunan Keuangan (Financial Development) diperoleh dari GFDD, sedangkan data Human Development Index diperoleh dari UNDP. Selain itu, beberapa data juga dicocokkan dengan data dari World Bank dan kantor statistik negara terkait (NSO).

\section{Metode Analisis}

Dalam penelitian ini digunakan dua jenis analisis yaitu analisis deskriptif dan inferensia. Analisis deskriptif dilakukan untuk mengetahui perkembangan beberapa variabel yang digunakan dalam penelitian dari tahun ke tahun beserta penjelasannya. Analisis deskriptif yang dilakukan berupa penjabaran grafik time-series dan tabel. Variabel yang dianalisis adalah pembangunan keuangan (rasio kredit swasta terhadap GDP, Return on Equity, Bank Z-score) sebagai proksi dari pertumbuhan ekonomi, Human Development Index sebagai proksi dari kemiskinan, dan Rasio Gini sebagai proksi dari ketimpangan.

Selanjutnya, analisis inferensia yang digunakan dalam penelitian ini adalah metode analisis regresi data panel. Dalam metode regresi data panel terdapat tiga model, yaitu common effect model (CEM), fixed effect model (FEM), dan random effect model (REM). Karena diasumsikan terdapat efek individu pada tiap negara, maka terdapat dua kemungkinan model yaitu fixed effect model dan random effect model.

\section{FEM}

GINI $_{i t}=\alpha_{0 \mathrm{i}}+\alpha_{1}$ PRIV_CRED ${ }_{i t}+$

$\alpha_{2} R O E_{i t}+\alpha_{3} Z_{i t}+\alpha_{4} H D I_{i t}+\mathrm{u}_{i t}$

\section{REM}

PRIV_CRED $D_{i t}=\beta_{0}+\beta_{1}$ GINI $_{i t}+$

$\beta_{2} H D I_{i t}+\mathrm{w}_{i t}$

$H D I_{i t}=\gamma_{0}+\gamma_{1} G_{N N I_{i t}}+$

$\gamma_{2}$ PRIV_CRED $D_{i t}+\mathrm{w}_{i t}$ dengan i: 1 (Indonesia), 2 (Malaysia), 3 (Singapura), 4 (Thailand), 5 (Filipina), 6 (Tiongkok), dan t: 2004-2016

Keterangan:

$\begin{array}{ll}\text { GINI } & : \text { Rasio gini } \\ \text { PRIV_CRED } & : \text { Rasio kredit swasta terhadap GDP } \\ \text { ROE } & : \text { Return on Equity } \\ Z & : \text { Bank Z-Score } \\ \text { HDI } & : \text { Human Development Index }\end{array}$

Model terbaik ditentukan dengan melakukan serangkaian pengujian, yakni uji Chow, Hausman test, dan Breusch-Pagan Lagrange Multiplier. Untuk menentukan model terbaik antara common effect dan fixed effect, digunakan uji Chow. Lalu dilakukan Uji Hausman untuk memilih model terbaik antara fixed effect dengan random effect. Terakhir menggunakan Uji Breusch-Pagan Lagrange Multiplier untuk memilih model terbaik antara common effect dengan random effect. Jika model yang terpilih adalah model fixed effect, maka perlu dilakukan pengujian lanjutan terhadap matriks sturktur varian-kovarians residual guna menentukan metode estimas i yang terbaik. Pengujian dilakukan untuk mengetahui apakah sifat dari struktur varian-kovarians residual homoskedastik atau heteroskedastik dan juga untuk mengetahui apakah terdapat cross-sectional correlation.

Setelah diperoleh model dan metode estimasi yang terbaik, dilanjutkan dengan pengujian asumsi dan keberartian model. Pengujian asumsi menggunakan uji normalitas dan non-multikolinearitas, sedangkan pengujian keberartian model menggunakan koefisien determinasi ( $\mathrm{R}^{2}$ adjusted), uji simultan $\mathrm{F}$, dan uji t parsial.

\section{HASIL DAN PEMBAHASAN}

\section{Gambaran Umum Ketimpangan \\ Pendapatan, Kemiskinan, dan Pembangunan Keuangan}

Secara garis besar, perkembangan distribusi pendapatan, pembangunan keuangan, dan kemiskinan di enam negara Asia dapat dijelaskan sebagai berikut: 


\section{Ketimpangan Pendapatan}

Rasio gini di negara-negara Asia cenderung berada di atas 0,4 yang merupakan batas wajar (Bock, 2014). Perubahan rasio gini di keenam negara cenderung memiliki tren negatif, yang berarti distribusi pendapatan semakin merata dari tahun ke tahun. Keberhasilan kebijakan pemerintah dalam melakukan distribusi pendapatan, baik melalui pembangunan inklusif, berkelanjutan, dan penciptaan kesempatan kerja adalah kunci dari penurunan nilai rasio gini (Bappenas, 2012).

Sebaliknya, Indonesia justru mengalami tren positif. Pada tahun 2004 hingga tahun 2007, rasio gini Indonesia merupakan yang terendah, namun pada tahun 2007 mengalami peningkatan tajam. Hal ini dikarenakan kenaikan harga komoditas selama beberapa tahun terakhir seperti minyak yang mengalami kenaikan harga secara internasional dan lebih banyak dinikmati oleh golongan yang kaya (Papanek, 2011 dalam Bappenas, 2012). Walaupun begitu, pada tahun 2014-2016 angka rasio gini Indonesia telah mengalami penurunan.

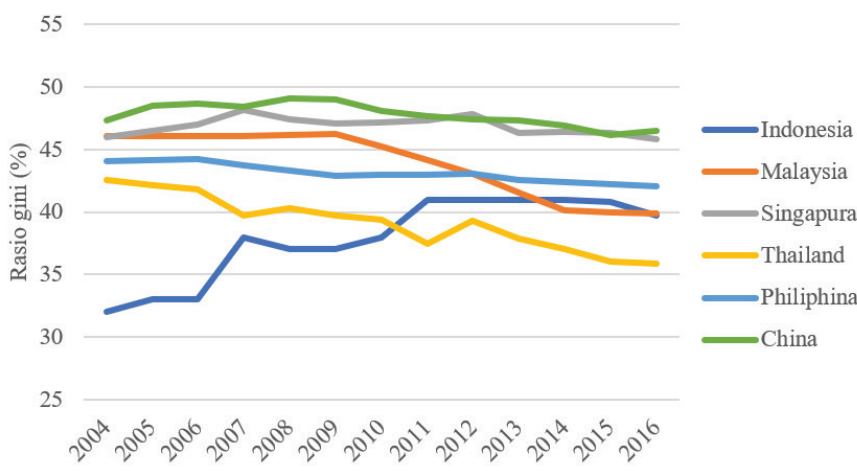

Gambar 4. Rasio gini enam negara Asia tahun 20042016

Sumber: World Bank (2018)

Di sisi lain, Tiongkok memiliki nilai koefisien gini yang lebih tinggi dibanding kelima negara lainnya. Hal ini dikarenakan pertumbuhan ekonomi dan urbanisasi secara masif yang dilakukan pada periode sebelumnya (Kopf, 2017).

\section{Human Development Index}

Dari Gambar 3 dapat dilihat bahwa semua negara memiliki tren positif, yang artinya terdapat peningkatan kualitas SDM dari tiap tiap negara. Singapura memiliki IPM tertinggi yang berarti dari aspek pendidikan, kesehatan, dan kemampuan beli penduduk di sana jauh lebih baik dari kelima negara lainnya. Salah satunya sistem layanan kesehatan yang diterapkan di Singapura sangat berkualitas dan mudah diakses oleh masyarakat, serta adanya program pemerintah yang bagus seperti Medishield dan Medifund (Carroll \& Frakt, 2017).

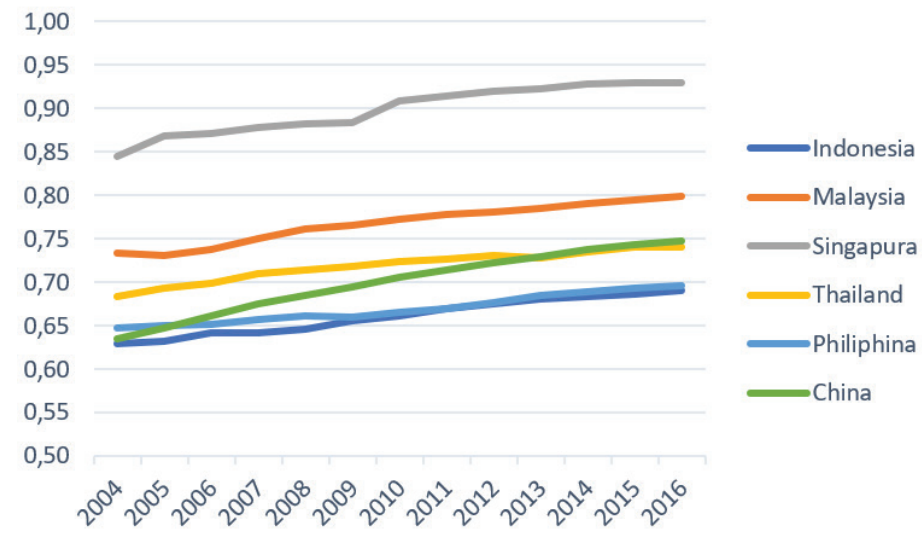

Gambar 5. Human Development Index enam negara Asia tahun 2004-2016

Sumber: UNDP (2018)

\section{Kredit swasta / GDP}

Salah satu komponen pembentukan modal adalah kredit. Sektor swasta sendiri membutuhkan kredit untuk membentuk suatu usaha atau mengekspansi usaha mereka. Sektor swasta yang dimaksud adalah usaha mikro-besar. Berdasarkan gambar 4, rasio kredit swasta terhadap PDB negara-negara di Asia cenderung fluktuatif dengan tren yang positif. Hal ini berarti bahwa naiknya PDB atau pertumbuhan ekonomi suatu negara diikuti dengan banyaknya pemberian atau permintaan kredit sektor swasta. Indonesia merupakan negara yang memiliki persentase kredit terhadap PDB terkecil diantara negara lainnya. Nilai indonesia minim dikarenakan tingginya financial exclusion dengan hanya terdapat $48 \%$ rumah tangga yang menabung di lembaga keuangan formal dan non formal, sedangkan sisanya tidak menabung (Bank Indonesia, 2014). 


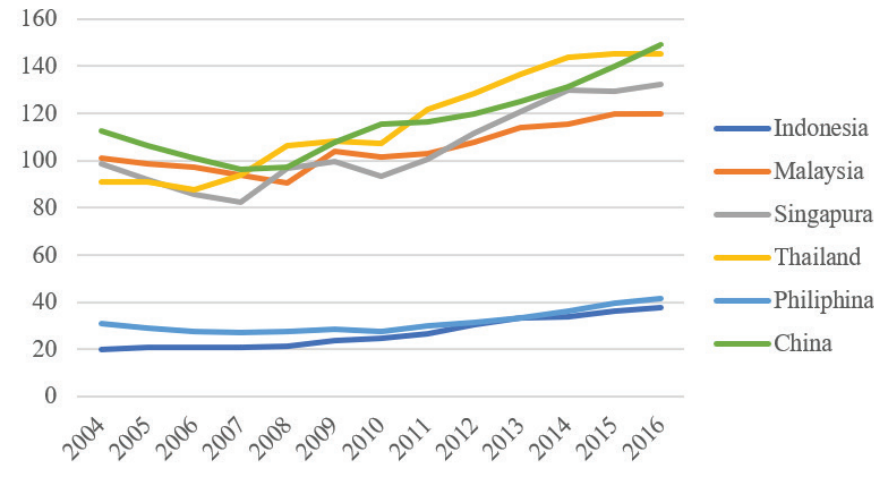

Gambar 6. Private Credits to GDP enam negara Asia tahun 2004-2016

Sumber: GFDD World Bank (2018)

\section{Determinan Ketimpangan Distribusi Pendapatan di Asia}

\section{Model Terbaik yang Terbentuk}

Model yang terpilih adalah model fixed effect dengan struktur matriks varians-kovarians residual bersifat heteroskedastik dan tidak terdapat cross-sectional correlation sehingga model estimasi yang digunakan adalah Weighted Least Squares (WLS).

Tabel 2. Ringkasan hasil estimasi fixed effect model dengan cross section-weight

\begin{tabular}{llll}
\hline Variabel & $\begin{array}{l}\text { Koefisien } \\
\text { Regresi }\end{array}$ & t-statistik & Prob \\
\hline$(1)$ & $(2)$ & $(3)$ & $(4)$ \\
\hline C & 34.59055 & 10.00828 & $0.0000^{* *}$ \\
\hline PRIV_CRED & -0.079823 & -8.661705 & $0.0000^{* *}$ \\
\hline ROE & 0.053486 & 1.714092 & $0.0911^{*}$ \\
\hline Z & -0.188859 & -3.615202 & $0.0006^{* *}$ \\
\hline HDI & 23.33259 & 3.951586 & $0.0002^{* *}$ \\
\hline Ringkasan Statistik & & \\
\hline Koefisien & 0,9425 & F-statistik & 141,4519 \\
Determinasi & & & \\
\hline \multicolumn{5}{c}{ p-value } & 0,0000 \\
\hline
\end{tabular}

Sumber: Hasil pengolahan data

Keterangan: *) Hasil signifikan pada $\alpha=10 \%$ $* *$ ) Hasil signifikan pada $\alpha=5 \%$

Berdasarkan hasil estimasi model pada tabel di atas, berikut ini adalah persamaan yang diperoleh dari hasil estimasi regresi data panel dengan menggunakan model fixed effect.

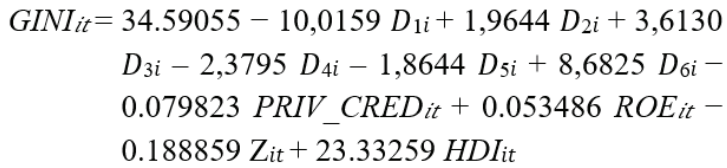

\section{Interpretasi Hasil Model Terbaik}

Sesuai dengan hasil yang tertera pada Tabel 2, rasio kredit swasta terhadap GDP memiliki pengaruh signifikan negatif terhadap Rasio gini. Hal tersebut ditunjukkan dengan nilai probabilitas t-statistik sebesar 0,0000 dan koefisien sebesar $-0,079823$. Jika variabel lain dianggap konstan, kenaikan ratio kredit swasta $G D P$ sebesar 1 satuan, akan menurunkan Rasio gini sebesar 0,0798 persen. Kondisi ini tentu sejalan dengan teori Galor \& Zeira (1993) yang menjelaskan bahwa pembangunan keuangan memiliki pengaruh penting dalam mengatasi ketimpangan pendapatan. Salah satunya adalah kredit yang dapat digunakan oleh penduduk untuk kegiatan yang produktif seperti usaha, investasi, dan pendidikan yang nantinya akan dapat mengurangi ketimpangan.

Selanjutnya, variabel Bank Z-Score memiliki pengaruh yang signifikan negatif terhadap Rasio gini. Hal tersebut ditunjukkan dengan nilai probabilitas t-statistik sebesar 0,006 dan koefisien sebesar -0,1888. Hal ini berarti bahwa, apabila variabel lain dianggap konstan, maka nilai $\mathrm{Z}$ Score yang naik sebesar 1 poin akan menurunkan Rasio gini rata-rata sebesar 0,1888 persen. Oleh karena itu, sejalan dengan hipotesis awal, yang mengatakan bahwa semakin baiknya kestabilan finansial suatu negara akan berpengaruh negatif atau dapat mengurangi ketimpangan distribusi pendapatan. 
Variabel ROE memiliki hubungan yang positif terhadap Rasio gini. Hal tersebut dibuktikan dengan nilai probabilitas t-statistik sebesar 0,0911. ROE memiliki koefisien sebesar 0,0534 yang berarti peningkatan ROE sebesar 1 satuan akan meningkatkan Rasio gini sebesar 0,0534 persen. Hal ini dikarenakan saham/ekuitas dari suatu perusahaan kebanyakan dimiliki oleh beberapa orang dewan direksi, sedangkan sisanya dilepas ke publik dalam jumlah kecil. Itupun dengan harga yang tidak murah, sehingga semakin meningkatnya ROE justru akan meningkatkan ketimpangan pendapatan (Tandelilin, 2010).

Kemudian untuk variabel Human Development Index, sesuai dengan hasil yang tertera pada Tabel 2, HDI memiliki pengaruh signifikan terhadap Rasio gini yang ditunjukkan dengan nilai probabilitas t-statistik sebesar 0,0002. Di dalam model, HDI memiliki koefisien sebesar 23,3325 yang berarti jika variabel lain dianggap konstan, maka kenaikan nilai HDI sebesar 1 satuan akan meningkatkan Rasio gini sebesar 0,2333 persen. Hal ini mengindikasikan bahwa HDI yang_terdiri dari dimensi pendidikan, kesehatan, dan daya beli masyarakat suatu negara yang bagus, belum tentu dapat membuat distribusi pendapatan merata. Dalam penelitian ini, dibuktikan bahwa HDI yang semakin tinggi justru memperparah ketimpangan.

Hal ini dapat dikaitkan dengan teori $U$-inverted Kuznets (1955) yang mengatakan bahwa pada awal pembangunan, pertumbuhan ekonomi akan meningkatkan ketimpangan, dalam hal ini dimensi daya beli yang tercakup dalam IPM berperan sebagai pertumbuhan ekonomi. Pada dimensi kesehatan, ketimpangan derajat kesehatan masih dapat dilihat antar tingkat sosial ekonomi. Oleh karena itu, dapat disimpulkan, pembangunan ekonomi baik dari faktor pendidikan, kesehatan, maupun daya beli masih berpihak pada satu golongan. Kelompok yang menguasai faktor produksi dan modal mendapatkan keuntungan yang lebih besar dibanding kelompok lainnya (miskin).

\section{Determinan Pertumbuhan Ekonomi di Asia 2004-2016}

Model Terbaik yang Terbentuk
Model Regresi Data Panel yang terpilih adalah model random effect.

Tabel 3. Ringkasan hasil estimasi random effect model

\begin{tabular}{llll}
\hline Variabel & $\begin{array}{l}\text { Koefisien } \\
\text { Regresi }\end{array}$ & $\begin{array}{l}\text { Uji } \\
\text { t-statistik }\end{array}$ & Prob \\
\hline$(1)$ & $(2)$ & $(3)$ & $(4)$ \\
\hline $\mathrm{C}$ & 447,6183 & 11,5959 & $0.0000^{*}$ \\
\hline $\mathrm{GINI}$ & $-2,300066$ & $-8,9201$ & $0.0000^{*}$ \\
\hline $\mathrm{HDI} 2$ & $-192,5004$ & $-4,4504$ & $0.0000^{*}$ \\
\hline Ringkasan Statistik & & \\
\hline $\begin{array}{l}\text { Koefisien } \\
\text { Determinasi }\end{array}$ & 0,5936 & Uji F & 57,2378 \\
\hline \multicolumn{5}{l}{} & p-value & 0,0000
\end{tabular}

Sumber: Hasil pengolahan data

Keterangan: *) Hasil signifikan pada $\alpha=5 \%$

Berdasarkan hasil estimasi model pada tabel di atas, berikut ini adalah persamaan yang diperoleh dari hasil estimasi regresi data panel dengan menggunakan model random effect.

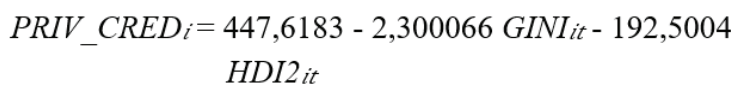

Keterangan:

$\mathrm{i}=$ Indonesia, Malaysia, Singapura, Thailand, Filipina, dan Tiongkok

$\mathrm{t}=2004-2016$

\section{Interpretasi Hasil Model Terbaik}

Berdasarkan olah data, dapat dihasilkan output dari estimasi persamaan pertumbuhan ekonomi sektor finansial yang digambarkan dengan rasio kredit swasta terhadap GDP enam negara Asia selama periode 2004-2016.

Sesuai dengan hasil yang tertera pada Tabel 3, Rasio gini memiliki hubungan signifikan terhadap rasio kredit swasta terhadap GDP. Hal tersebut ditunjukkan dengan nilai probabilitas t-statistik sebesar 0,0000 . Untuk pengaruh rasio kredit swasta terhadap GDP terhadap Rasio gini sesuai dengan model yang terbentuk, memiliki koefisien -2,3 yang berarti jika variabel lain dianggap konstan, kenaikan rasio gini sebesar 1 satuan, akan menurunkan rasio kredit swasta terhadap GDP rata-rata sebesar 2,3 persen. Oleh karena itu dapat diartikan ketika nilai rasio gini 
tinggi, perbankan enggan untuk memberikan kredit, hal ini dikarenakan tingginya risiko, kurangnya jaminan dan kecilnya keuntungan yang diperoleh perbankan. Padahal sesuai dengan Peraturan Bank Indonesia Nomor 14/22/PBI/2012 industri perbankan di Tanah Air diharapkan terus meningkatkan porsi kredit kepada masyarakat kecil dan Usaha Mikro Kecil dan Menengah (UMKM) terutama di daerah, karena pembiayaan itu dapat berpengaruh terhadap perbaikan rasio gini di daerah tersebut.

Kemudian untuk variabel HDI memiliki hubungan yang signifikan, namun karena menggunakan Tukey's ladder of power transformation maka tidak dapat diartikan arah hubungan sesuai dengan output koefisien pada Tabel 3. Namun menurut (Tukey, 1977) dapat diinterpretasikan dengan setiap kenaikan HDI sebesar 1 satuan, akan menaikkan Private Credit to GDP sebesar 5,1 x $10^{-5}$ persen. Hasil tersebut mengindikasikan bahwa terdapat hubungan positif antara HDI dan rasio kredit swasta terhadap GDP, yang berarti jika kualitas SDM meningkat, akan diikuti oleh peningkatan daya beli dan tingkat pendidikan dari masyarakat. Sehingga lembaga keuangan akan lebih berani untuk memberi fasilitas kredit, karena latar belakang nasabah yang dianggap mampu dan mengurangi risiko kredit macet.

\section{Determinan Pembangunan Manusia di Asia 2004-2016}

\section{Model Terbaik yang Terbentuk}

Model Regresi Data Panel yang terbaik adalah model random effect.

Tabel 4. Ringkasan hasil estimasi random effect model

\begin{tabular}{llll}
\hline Variabel & $\begin{array}{l}\text { Koefisien } \\
\text { Regresi }\end{array}$ & $\begin{array}{l}\text { Uji t- } \\
\text { statistik }\end{array}$ & Prob \\
\hline$(1)$ & $(2)$ & $(3)$ & $(4)$ \\
\hline $\mathrm{C}$ & 0,534484 & 8,422728 & $0,0000^{* *}$ \\
\hline GINI & 0,001856 & 1,770692 & $0,0807^{*}$ \\
\hline PRIV_CRED & 0,001450 & 9,650582 & $0,0000^{* *}$ \\
\hline Ringkasan Statistik & & \\
\hline $\begin{array}{l}\text { Koefisien } \\
\text { Determinasi }\end{array}$ & 0,5648 & Uji F & 50,9706 \\
\hline \multicolumn{4}{l}{ p-value } \\
\hline
\end{tabular}

Sumber: Hasil pengolahan data
Keterangan:

*) Hasil signifikan pada $\alpha=10 \%$

**) Hasil signifikan pada $\alpha=5 \%$

Berdasarkan hasil estimasi model pada tabel di atas, berikut ini adalah persamaan yang diperoleh dari hasil estimasi regresi data panel dengan menggunakan model random effect.

$$
\begin{aligned}
H D I_{i}= & 0,534484+0,001856 G^{2} I_{i t}+0,001450 \\
& \text { PRIV_CRED } i t
\end{aligned}
$$

Keterangan:

$\mathrm{i}=$ Indonesia, Malaysia, Singapura, Thailand, Philiphina, dan Tiongkok

$\mathrm{t}=2004-2016$

\section{Interpretasi Hasil Model Terbaik}

Berdasarkan hasil pengolahan sesuai pada Tabel 4, dapat dijelaskan bahwa variabel GINI tidak berpengaruh signifikan dan PRIV_CRED berpengaruh secara signifikan terhadap $H D I$ enam negara Asia. Hal ini dapat dilihat dari uji parsial yaitu nilai t-statistik dan nilai prob pada tabel.

Untuk variabel rasio kredit swasta terhadap $G D P$, sesuai dengan hasil yang tertera pada Tabel 4, rasio kredit swasta terhadap GDP memiliki pengaruh yang signifikan positif terhadap HDI. Hal ini ditunjukkan dengan nilai probabilitas t-statistik sebesar 0,0000 dan koefisien sebesar 0,001450 . Hal ini berarti bahwa apabila variabel lain dianggap konstan, maka kenaikan rasio kredit swasta terhadap GDP sebesar 1 satuan akan dapat menaikkan HDI sebesar 0,1450 persen. Hasil tersebut menunjukkan bahwa jika lembaga keuangan memberikan fasilitas kredit semakin banyak, maka kredit tersebut dapat digunakan untuk kegiatan produktif seperti meningkatkan kualitas SDM melalui pendidikan dan investasi modal bagi masyarakat, sehingga pada akhirnya akan meningkatkan kualitas hidup dari masyarakat itu sendiri, sejalan dengan teori Galor \& Zeira (1993).

Hal ini juga sejalan dengan penelitian Sumanto (2016) yang menyebutkan bahwa penyaluran kredit dalam jangka pendek dapat meningkatkan kesejahteraan masyarakat. Hal ini dikarenakan kredit menyebabkan perusahaan tetap hidup di tengah persaingan usaha yang semakin sengit. Kelangsungan usaha ini pada 
akhirnya akan berakibat kepada kesejahteraan tenaga kerja dalam bentuk peningkatan daya beli, pendidikan dan pelayanan kesehatan yang lebih baik.

Untuk variabel Rasio gini, memiliki koefisien yang positif sehingga dapat diartikan semakin meningkatnya Rasio gini sebesar 1 satuan, akan meningkatkan HDI sebesar 0,0018 persen. Oleh karena itu, semakin timpangnya distribusi pendapatan di suatu negara dapat berarti semakin tingginya pendapatan yang diperoleh oleh $40 \%$ kelas penerima pendapatan menengah dan $20 \%$ tertinggi. Hal ini akan meningkatkan daya beli mereka sehingga akan meningkatkan nilai HDI secara rata-rata.

\section{KESIMPULAN}

Berdasarkan hasil analisis yang telah dipaparkan dalam bagian sebelumnya, dapat diambil kesimpulan bahwa ketimpangan distribusi pendapatan sejak 2004 hingga 2016 secara rata-rata di enam negara Asia semuanya berada di rentang ketimpangan sedang. Apabila dilihat dari indikator pembangunan keuangan, Indonesia dan Filipina merupakan negara dengan tingkat pembangunan keuangan yang rendah jika dibandingkan dengan negara lainnya. Akibatnya, penurunan dari nilai rasio gini hanya sedikit, bahkan di Indonesia justru meningkat di beberapa tahun awal. Selain itu, pembangunan manusia pada keenam negara terus meningkat dengan Singapura sebagai negara yang memiliki pembangunan manusia paling unggul. Secara keseluruhan terdapat hubungan antara ketiga variabel (Rasio gini, Human Development Index, dan rasio kredit swasta terhadap $G D P$ ) yang disebutkan dalam PGI Triangle sesuai dengan teori-teori sebelumnya. Semakin berkembang pembangunan keuangan suatu negara, maka akan menurunkan ketimpangan di negara tersebut dan akan meningkatkan Human Development Index.

Terdapat beberapa saran yang dapat diberikan berdasarkan hasil dan pembahasan serta kesimpulan dari penelitian ini, antara lain: Pertama, pemerintah sebaiknya meningkatkan peran sektor finansial terhadap penduduk kurang mampu dan berpendapatan rendah melalui kredit dengan bunga rendah, serta Gerakan
Indonesia Menabung (GIM) sehingga dapat mengurangi ketimpangan distribusi pendapatan melalui kredit bunga rendah. Kedua, saran untuk penelitian selanjutnya adalah menggunakan analisis simultan pada hubungan ketiga variabel PGI, yaitu kemiskinan, pertumbuhan ekonomi, dan ketimpangan agar dapat menggambarkan keadaan yang lebih rinci. Serta menambahkan variabel yang mungkin dapat mempengaruhi, seperti investasi asing langsung (foreign direct investment) dan inflasi.

\section{DAFTAR PUSTAKA}

Astuti, S. P. (2013). Financial Development dan Kesenjangan Pendapatan : Kajian Empiris Negara-Negara di Kawasan Uni Eropa dan ASEAN-6. Bogor: Institut Pertanian Bogor.

Bank Indonesia. (2014). Buku Saku Keuangan Inklusif: Survey Neraca Rumah Tangga BI.

Bappenas. (2006). Poverty reduction in Indonesia: A brief review of facts, effort and ways forward. Forum on National Plans and PRSPs in East Asia.

Bappenas. (2012). Rasio gini di Indonesia dalam Lima Tahun Terakhir Trend Peningkatan Ketimpangan.

Bock, Matthew J. (2014). Income Inequality in AEAN: Perceptions on Regional Stability from Indonesia and the Philippines. ASEANCanada Research Partnership, Working Paper No.1.

Bourguignon, F. (2004). The Poverty-GrowthInequality Triangle. New Delhi: International Economic Relations.

Brata, A. G. (2002). Pembangunan Manusia Dan Kinerja Ekonomi Regional Di Indonesia. Ekonomi Pembangunan, 7(2), 113-122.

Buhaerah, P. (2017). Pengaruh Finansialisasi Terhadap Ketimpangan Pendapatan Di Asean : Analisis Data Panel. Buletin Ekonomi Moneter Dan Perbankan, 19(3), 335-352.

Carroll, A. E., \& Frakt, A. (2017). What Makes Singapore's Health Care So Cheap? The New York Times. Diakses melalui https:// www.nytimes.com/2017/10/02/upshot/ 
what-makes-singapores-health-care-socheap.html

Galor, O., \& Zeira, J. (1993). Income Distribution and Macroeconomics. Review of Economic Studies, 60(1), 35-52.

IMF. (2016). Introducing a New Broad-based Index of Financial Development. IMF Working Paper. IMF Strategy, Policy, and Review Department.

Jallian, H., \& Kirkpatrick, C. (2005). Does Financial Development Contribute to Poverty Reduction?. The Journal of Development Studies, 41(4), 636-656.

Kindleberger, Charles. P. (1988). Ekonomi Pembangunan Jilid 1. Jakarta : Bina Aksara.

Kopf, D. (2017). China's extreme income inequality finally appears to be falling. Quartz. Diakses melalui https://qz.com/937137/chinasextreme-income-inequality-appears-to-be improving-after-decades-of-deterioration/

Kuncoro, M. (2006). Ekonomi Pembangunan. Jakarta: Salemba Empat.

Kuznets, S. (1955). Economic Growth and Income Inequality. The American Economic Review, $45(1), 1-28$.

Levine, R. (2005). Chapter 12 Finance and Growth: Theory and Evidence. Handbook of Economic Growth, 1(A) 865-934.

Persson, T., \& Tabellini, G. (1991). Is Inequality Harmful for Growth? Theory and Evidence. The American Economic Review, 84(3), 600-621.

Rajan, R. G., \& Zingales, L. (2003). The great reversals: The politics of financial development in the twentieth century. Journal of Financial Economics, 69(1) 5-50.

Sen, A. (1976). Poverty: An Ordinal Approach to Measurement. Econometrica.
Shaw, E. \& McKinnon, R. (1973), Financial Deepening in Economic Development. New York: Oxford University Press.

Sumanto, A. (2016). Pengaruh Kredit Investasi dan Kredit Modal Kerja Terhadap Kesejahteraan Masyarakat Kabupaten/Kota di Jawa Timur. Jurnal Ekonomi dan Studi Pembangunan, 8(1) 1-13.

Tandelilin, E. (2010). Portofolio dan Investasi Teori dan Aplikasi. Yogyakarta: Kanisius.

Todaro, M. P. (1994). Pembangunan Ekonomi di Dunia Ketiga Edisi keempat Jilid I. Jakarta: Erlangga.

Tukey, J. W. (1977). Exploratory Data Analysis. Boston: Addison-Wesley.

UNDP. (2013). Human Development Report 2013. New York. Diakses melalui http://hdr. undp.org/en/content/human-developmentreport-2013.

UNDP. (2019). Human Development Data Bank. Diakses melalui http://hdr.undp.org/en/ content/human-development-index-hdi

Wan, G. (2008). Poverty-Growth-Inequality Triangle in China. United Nations University: UNU Wider. Diakses melalui https://www.wider.unu.edu/publication/ poverty-growth-inequality-triangle-china. World Bank. (2009). Handbook on Poverty and Inequality. New York: The World Bank.

World Bank. (2015). Indonesia's Rising Divide. The World Bank. Diakses melalui https://www. worldbank.org/en/news/feature/2015/12/08/ indonesia-rising-divide

World Bank. (2018). World Income Inequality Database. The World Bank. Diakses melalui https://www.wider.unu.edu/project/wiidworld-income-inequality-database 
